\title{
HUBUNGAN ANTARA UKURAN DIMENSI TUBUH DENGAN BOBOT5 BADAN KAMBING KACANG (Capra hircus) DI DAERAH TRANSMIGRASI DAN NON TRANSMIGRASI DI KABUPATEN MUNA
}

\author{
Yunus ${ }^{1)}$, La Ode Ba'a ${ }^{2)}$ dan Muh. Amrullah Pagala ${ }^{2)}$ \\ ${ }^{1)}$ Alumnus Fakultas Peternakan UHO \\ ${ }^{2)}$ Dosen Fakultas Peternakan UHO \\ Email: amroe74@gmail.com
}

\begin{abstract}
ABSTRAK
Tujuan penelitian ini adalah untuk mengetahui dan menganalisis hubungan antara ukuranukuran tubuh (panjang badan, lingkar dada, tinggi pundak) dengan bobot badan kambing kacang di Daerah Transmigrasi dan Non transmigrasi di Kabupaten Muna. Penelitian ini dilakukan pada bulan Februari - Maret 2016. Materi penelitian sebanyak 244 ekor yang terdiri atas 118 ekor jantan dan 126 ekor betina, kemudian dikelompokkan berdasarkan umur ternak yaitu umur $\leq 12$ bulan $\left(\mathrm{G}_{1}\right)$, umur 13 - 24 bulan $\left(\mathrm{G}_{2}\right)$, dan umur $>24$ bulan $\left(\mathrm{G}_{3}\right)$. Observasi dan pengukuran dilakukan untuk mengumpulkan data hubungan dari pengukuran variabel. Hasil penelitian di daerah Transmigrasi menunjukan bahwa bobot badan kambing kacang jantan dan betina $\mathrm{G}_{1}$ berkorelasi sangat kuat dengan tinggi pundak $(r=0,870$; dan $r=0,890)$, sedangkan kambing jantan dan betina $\mathrm{G}_{2}$ berkorelasi sangat kuat dengan panjang badan dan tinggi pundak $(\mathrm{r}=0,852$; dan $\mathrm{r}=0,566)$ kambing jantan dan betina $\mathrm{G}_{3}$ berkorelasi sangat kuat dengan lingkar dada dan panjang badan $(\mathrm{r}=0,872$; dan $\mathrm{r}=0,667)$. Hasil penelitian di daerah Non transmigrasi menunjukan bahwa bobot badan kambing kacang jantan dan betina $\mathrm{G}_{1}$ berkorelasi sangat kuat dengan tinggi pundak dan panjang badan $(\mathrm{r}=0,876$; dan $\mathrm{r}=$ $0,836)$, kambing jantan dan betina $\mathrm{G}_{2}$ berkorelasi sangat kuat dengan tinggi pundak $(\mathrm{r}=0,604$; dan $\mathrm{r}=0424$, kambing jantan dan betina $\mathrm{G}_{3}$ berkorelasi sangat kuat dengan tinggi pundak dan lingkar dada $(r=0,284$; dan $r=0,253)$. Kesimpulan dari penelitian ini adalah tinggi pundak memiliki korelasi paling kuat dengan bobot badan.
\end{abstract}

Kata Kunci : Dimensi Tubuh, Bobot Badan, Kambing Kacang.

\begin{abstract}
The purpose of this research was to find out and analyze the relationship between body measurements (length, circumference, chest height, shoulders height) and the body weight of kacang goat in transmigration area and Non transmigration in Muna. This research was conducted in February-March 2016. Research material were 244 goat, consisted 118 male and 126 females, then grouped by age; age $\leq 12$ months (G1), age 13-24 months (G2), and age > 24 months (G3). Observations and measurements were conducted to collect data on the relationship of measurement variables. The results showed that in transmigration areas, the weight of the body of the goat G1 males and females was correlated very strongly with shoulders height $(r=0.870$; and $r=0,890)$, while the male and the females of G2 are correlated very strongly with length and shoulder height $(\mathrm{r}=$ 0.852 ; and $\mathrm{r}=0.566$ ) male and female of G3 are correlated very strongly with the circumference of the chest and length $(r=0.872$; and $r=0.667)$. The results in non transmigration area showed that the body weight of male and female goat of G1 group was correlated very strongly with shoulders height and length $(\mathrm{r}=0.876$; and $\mathrm{r}=0.860)$, male and female of was G2 correlated very strongly with shoulders height $(\mathrm{r}=0.604$; and $\mathrm{r}=0424$, male and female of was $\mathrm{G} 3$ correlated very strongly with shoulders height and chest circumference $(r=0.284$; and $r=0,253)$. The conclusion of study is that shoulders height has the strongest correlation with body weight.
\end{abstract}

Key words: Body Dimention, Body Weight, Kacang Goat

\footnotetext{
${ }^{*}$ Corresponding author
} 


\section{PENDAHULUAN}

Kambing merupakan ternak ruminansia yang banyak diternakkan masyarakat Indonesia sebagai penghasil daging. Potensi pengembangan kambing untuk memenuhi kebutuhan daging sangat baik karena kambing mampu berkembang biak dengan baik pada lahan tandus, lahan berbatubatu dan daya adaptasi tinggi terhadap cuaca panas. Kambing banyak dipelihara oleh peternak di pedesaan karena dalam pemeliharaannya mudah dilakukan dan kambing memiliki kemampuan memanfaatkan pakan berkualitas rendah serta modal usaha untuk beternak kambing relatif lebih kecil.

Kambing yang banyak diternakkan masyarakat di Kabupaten Muna adalah kambing kacang. Ciri-ciri kambing kacang: badan kecil, telinga pendek tegak, leher pendek, punggung meninggi, jantan dan betina bertanduk, , bobot dewasa untuk betina ratarata $20 \mathrm{~kg}$ dan jantan $25 \mathrm{~kg}$ (Agung, 2010). Ternak kambing kacang mempunyai peranan yang sangat besar dalam kehidupan masyarakat di Kabupaten Muna khususnya hari besar agama islam seperti hari raya idul adha, maupun acara Aqiqah.

Umumnya ternak kambing di

Kabupaten Muna dipelihara oleh petani transmigrasi dan petani non transmigrasi (lokal). Selain beternak, masyarakat lokal sebagian besar bekerja sebagai petani tradisional yang bercocok tanam dengan berpindah-pindah tempat sehingga lebih fokus pada usaha pertanian. Ternak hanya dijadikan hewan peliharaan yang sewaktu-waktu bisa dijual, khususnya ternak kambing yang dilepas mencari makanan sendiri. Saat musim hujan, hijaun tumbuh subur sehingga ternak mudah mendapat makanan, namun saat musim kemarau ketersediaan hijauan menurun sehingga ternak sulit untuk memperoleh makanan. Berbeda dengan masyarakat transmigrasi, peternak transmigrasi tidak melepas ternak mencari makanan sendiri melainkan peternak bekerja mencari makanan untuk kambing dan dibawakan dikandang. Kebutuhan makanan kambing tetap terpenuhi sepanjang tahun baik musim hujan maupun musim kemarau. Perbedaan pola pemeliharaan dan pemberian pakan dari kedua peternak tersebut akan mempengaruhi produktivitas ternak kambing.
Salah satu parameter yang dapat digunakan untuk mengukur produktivitas ternak kambing adalah bobot badan. Bobot badan dapat diketahui dengan menimbang ternak kambing. Selain itu, bobot badan dapat diestimasi dengan mengukur bagian-bagian tubuh tertentu seperti panjang badan, lingkar dada, dan tinggi pundak.

\section{METODOLOGI PENELITIAN}

Penelitian ini dilakukan pada bulan Februari-Maret 2016 di daerah transmigrasi dan non transmigrasi di Kabupaten Muna. Teknik pengumpulan data yang digunakan adalah pengamatan langsung di lapangan dengan menimbang bobot badan dan mengukur ukuran-ukuran-ukuran tubuh (panjang badan, lingkar dada, tinggi pundak). Kambing peternak dibagi atas 3 kelompok umur yaitu ternak umur $\leq 12$ bulan $\left(\mathrm{G}_{1}\right), 13$ 24 bulan $\left(\mathrm{G}_{2}\right)$, 24 bulan $\left(\mathrm{G}_{3}\right)$ yang ditentukan dengan pergantian gigi seri/ dentis incisive (Mersi, 2014). Pengambilan sampel ditentukan secara purposive sampling yaitu dipilih Kecamatan yang memiliki populasi ternak kambing terbanyak, terpilih dua Kecamatan masing-masing adalah Kecamatan Kabangka terdiri dari dua desa yaitu desa Wakobalu Agung dan desa Sarimulyo, Kecamatan Kontunaga terdiri dari dua desa yaitu desa Bungi dan desa Mabodo dengan ketentuan desa tersebut mewakili daerah transmigrasi dan non transmigrasi. Data yang diperoleh dari pengukuran ditabulasi dan dianalisis dengan menggunakan program aplikasi Minitab versi 16.

\section{HASIL DAN PEMBAHASAN}

\section{A. Rataan Ukuran Dimensi Tubuh dan Bobot Badan Kambing Kacang di Daerah Transmigrasi dan Non Transmigrasi di Kabupaten Muna}

Rataan bobot badan dan ukuran dimensi tubuh kambing kacang di daerah transmigrasi dan non transmigrasi disajikan pada Tabel 1. 
Tabel 1. Rataan Bobot Badan dan Ukuran Dimensi Tubuh Kambing Kacang di Daerah Transmigrasi dan Non transmigrasi di Kabupaten Muna

\begin{tabular}{|c|c|c|c|c|c|c|}
\hline Umur & $\begin{array}{c}\text { Jenis } \\
\text { Kelamin } \\
\end{array}$ & $\begin{array}{c}\text { Jumlah } \\
\text { (ekor) }\end{array}$ & $\begin{array}{l}\mathrm{BB} \\
(\mathrm{kg})\end{array}$ & $\begin{array}{l}\text { PB } \\
(\mathrm{cm})\end{array}$ & $\begin{array}{c}\mathrm{TP} \\
(\mathrm{cm})\end{array}$ & $\begin{array}{l}\mathrm{LD} \\
(\mathrm{cm})\end{array}$ \\
\hline \multicolumn{7}{|c|}{ Daerah transmigrasi } \\
\hline \multirow[t]{2}{*}{$\leq 12$ Bulan } & Jantan & 17 & $8.8 \pm 3.3$ & $39.9 \pm 8.3$ & $41.8 \pm 5.1$ & $51.6 \pm 10.7$ \\
\hline & Betina & 20 & $8.0 \pm 2.2$ & $34.5 \pm 4.8$ & $40.6 \pm 5.4$ & $49.5 \pm 6.2$ \\
\hline \multirow[t]{2}{*}{$13-24$ Bulan } & Jantan & 22 & $17.7 \pm 3.0$ & $54.1 \pm 2.4$ & $53.9 \pm 4.7$ & $64.8 \pm 3.6$ \\
\hline & Betina & 21 & $17.1 \pm 2.4$ & $48.1 \pm 2.4$ & $49.5 \pm 2.4$ & $59.8 \pm 2.4$ \\
\hline \multirow[t]{2}{*}{$>24$ Bulan } & Jantan & 20 & $19.2 \pm 2.3$ & $50.8 \pm 4.7$ & $53.4 \pm 5.3$ & $61.1 \pm 5.5$ \\
\hline & Betina & 22 & $18.7 \pm 2.7$ & $54.8 \pm 3.9$ & $56.5 \pm 4.2$ & $63.1 \pm 4.5$ \\
\hline \multicolumn{7}{|c|}{ Daerah non transmigrasi } \\
\hline \multirow[t]{2}{*}{$\leq 12$ Bulan } & Jantan & 17 & $7.3 \pm 3.4$ & $32.2 \pm 11.1$ & $36.4 \pm 6.7$ & $44.2 \pm 7.8$ \\
\hline & Betina & 20 & $7.1 \pm 2.7$ & $33.1 \pm 5.9$ & $37.9 \pm 8.5$ & $44.4 \pm 7.8$ \\
\hline \multirow[t]{2}{*}{$13-24$ Bulan } & Jantan & 22 & $15.7 \pm 3.5$ & $47.3 \pm 8.2$ & $50.1 \pm 6.1$ & $57.2 \pm 8.7$ \\
\hline & Betina & 21 & $15.1 \pm 1.7$ & $48.2 \pm 6.2$ & $48.9 \pm 5.5$ & $52.3 \pm 10.2$ \\
\hline \multirow[t]{2}{*}{$>24$ Bulan } & Jantan & 20 & $17.1 \pm 2.7$ & $48.7 \pm 3.8$ & $52.8 \pm 3.2$ & $58.3 \pm 7.5$ \\
\hline & Betina & 22 & $17.3 \pm 2.2$ & $51.2 \pm 6.9$ & $53.1 \pm 3.7$ & $62.3 \pm 7.3$ \\
\hline
\end{tabular}

Keterangan: $\mathrm{BB}=$ Bobot Badan, $\mathrm{PB}=$ Panjang Badan, $\mathrm{TP}=$ Tinggi Pundak,

LD = Lingkar Dada.

Berdasarkan data pada Tabel 1, rataan bobot badan kambing kacang jantan dan betina di daerah transmigrasi paling tinggi terdapat pada umur $>24$ bulan masing-masing $19,2 \pm 2,3$ dan $18,7 \pm 2,7 \mathrm{~kg}$. Sedangkan rataan bobot badan kambing kacang jantan dan betina paling rendah terdapat pada umur $\leq 12$ bulan masing-masing $8,8 \pm 3,3$ dan $8,0 \pm 2,2 \mathrm{~kg}$. Rataan ukuran dimensi tubuh tertinggi kambing kacang jantan dan betina di daerah transmigrasi terdapat pada kisaran umur $>24$ bulan masing-masing : panjang badan $50,8 \pm 4,7 ; 54,8 \pm 3,9$, tinggi pundak $53,4 \pm 5,3$; $56,5 \pm 4,2$, lingkar dada $61,1 \pm 5,5 ; 63,1 \pm 4,5$. Rataan ukuran dimensi tubuh paling rendah terdapat pada umur $\leq 12$ bulan masing-masing panjang badan $39,9 \pm 8,3 ; 34,5 \pm 4,8$, tinggi pundak $41,8 \pm 5,1 ; 49,5 \pm 6,2$, lingkar dada $51,6 \pm 10,7 ; 49,5 \pm 6,2$.

Berdasarkan data pada Tabel 1, rataan bobot badan kambing kacang jantan dan betina di daerah non transmigrasi paling tinggi terdapat pada umur $>24$ bulan masing-masing $17,1 \pm 2,7$ dan $17,3 \pm 2,2 \mathrm{~kg}$. Sedangkan rataan bobot badan kambing kacang jantan dan betina paling rendah terdapat pada umur $\leq 12$ bulan

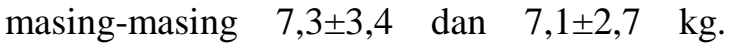
Rataan ukuran dimensi tubuh tertinggi kambing kacang jantan dan betina di daerah non transmigrasi terdapat pada kisaran umur > 24 bulan masing-masing : panjang badan
$48,7 \pm 3,8 ; 51,2 \pm 6,9$, tinggi pundak $52,8 \pm 3,2$; $53,1 \pm 3,7$, lingkar dada $58,3 \pm 7,5 ; 62,3 \pm 7,3$. Rataan ukuran dimensi tubuh paling rendah terdapat pada umur $\leq 12$ bulan masing-masing panjang badan $32,2 \pm 11,1 ; 33,1 \pm 5,9$, tinggi pundak $36, \pm 6,7 ; \quad 37,9 \pm 8,5$, lingkar dada $44,2 \pm 7,8 ; 44,4 \pm 7,8$.

Hasil penelitian ini lebih besar jika dibandingkan dengan hasil penelitian Mersi (2014) yaitu bobot badan kambing kacang jantan di Kecamatan Binongko pada umur > 24 bulan adalah $16,0 \pm 2,12 \mathrm{~kg}$ dan kambing betina 17,0 $\pm 8,27 \mathrm{~kg}$. Ramusia (2011), melaporkan hasil penelitian di Konawe Utara bahwa rataan bobot badan kambing kacang jantan sebesar $18,7 \mathrm{~kg}$ dan pada kambing betina 18,9 kg. Bobot badan kambing kacang jantan di Kecamatan Soropia adalah 20,26 kg dan kambing betina 17,36 kg (Yusnadirawan, 2005) dan lebih kecil dari hasil penelitian Adsmi (2005) di Kecamatan Moramo yaitu bobot badan kambing kacang jantan 24,19 kg, kambing betina 23,18 kg. Batubara (2011) menambahkan bahwa rataan bobot badan kambing kacang jantan 24,67 kg dan kambing kacang betina $21,61 \mathrm{~kg}$.

\section{B. Hubungan antara Bobot Badan dan Ukuran-Ukuran Tubuh}


Hubungan antara bobot badan dan ukuran dimensi tubuh kambing kacang di daerah transmigrasi dan non transmigrasi disajikan pada Tabel 2.

Tabel 2. Koefisien Korelasi Antara Ukuran Dimensi Tubuh dan Bobot Badan Kambing Kacang Jantan dan Betina di Daerah Transmigrasi dan Non transmigrasi

\begin{tabular}{|c|c|c|c|c|c|c|}
\hline \multirow[t]{2}{*}{ Umur } & \multirow{2}{*}{$\begin{array}{l}\text { Ukuran } \\
\text { Tubuh }\end{array}$} & \multirow{2}{*}{$\begin{array}{c}\text { Jenis } \\
\text { Kelamin }\end{array}$} & \multicolumn{2}{|c|}{ Transmigrasi } & \multicolumn{2}{|c|}{ Non transmigrasi } \\
\hline & & & $\mathrm{r}$ & $\mathrm{s}$ & $\mathrm{r}$ & $\mathrm{s}$ \\
\hline \multirow[t]{6}{*}{$\leq 12$ bulan } & Panjang badan & Jantan & 0.861 & 0.000 & 0.633 & 0.006 \\
\hline & & Betina & 0.869 & 0.000 & 0.836 & 0.000 \\
\hline & Tinggi pundak & Jantan & 0.874 & 0.000 & 0.876 & 0.000 \\
\hline & & Betina & 0.890 & 0.000 & 0.756 & 0.000 \\
\hline & Lingkar dada & Jantan & 0.756 & 0.000 & 0.850 & 0.000 \\
\hline & & Betina & 0.772 & 0.000 & 0.640 & 0.002 \\
\hline \multirow{6}{*}{$\begin{array}{c}13-24 \\
\text { bulan }\end{array}$} & Panjang badan & Jantan & 0.852 & 0.000 & 0.410 & 0.065 \\
\hline & & Betina & 0.508 & 0.019 & -0.056 & 0.810 \\
\hline & Tinggi pundak & Jantan & 0.823 & 0.000 & 0.604 & 0.004 \\
\hline & & Betina & 0.566 & 0.007 & 0.424 & 0.055 \\
\hline & Lingkar dada & Jantan & 0.513 & 0.015 & 0.310 & 0.172 \\
\hline & & Betina & 0.240 & 0.295 & 0.129 & 0.579 \\
\hline \multirow[t]{6}{*}{$>24$ bulan } & Panjang badan & Jantan & 0.588 & 0.006 & 0.070 & 0.769 \\
\hline & & Betina & 0.677 & 0.001 & -0.177 & 0.431 \\
\hline & Tinggi pundak & Jantan & 0.560 & 0.010 & 0.284 & 0.225 \\
\hline & & Betina & 0.645 & 0.645 & -0.029 & 0.899 \\
\hline & Lingkar dada & Jantan & 0.872 & 0.000 & 0.056 & 0.815 \\
\hline & & Betina & 0.448 & 0.037 & 0.253 & 0.255 \\
\hline
\end{tabular}

Keterangan : $\mathrm{r}=$ Koefisien korelasi, $\mathrm{s}=$ Signifikansi

Data pada Tabel 2 menunjukan bahwa untuk menentukan bobot badan kambing kacang jantan dan betina di daerah transmigrasi pada umur $\leq 12$ bulan adalah tinggi pundak dengan nilai korelasi masingmasing 0,874 dan 0,890. Pada umur $13-24$ bulan untuk menentukan bobot badan kambing kacang jantan adalah panjang badan dengan nilai korelasi 0,852 dan kambing betina adalah tinggi pundak dengan nilai korelasi 0,566. Sementara untuk menentukan bobot badan kambing kacang jantan umur > 24 bulan adalah lingkar dada dengan nilai korelasi 0,872, untuk menentukan bobot badan kambing kacang betina adalah panjang badan dengan nilai korelasi 0,677.

Hasil penelitian ini berbeda dengan hasil penelitian Mersi (2014) yaitu ukuran tubuh yang lebih tepat untuk menduga bobot badan kambing kacang jantan pada umur $>24$ bulan adalah tinggi pundak dengan nilai korelasi 0,852 sedangkan kambing betina adalah lingkar dada dengan nilai korelasi 0,951. Rosmin (2002) menyatakan bahwa ukuran tubuh yang lebih tepat untuk menduga bobot badan adalah lingkar dada, karena lingkar dada mempunyai koefisien korelasi (r) tertinggi untuk jantan ( $\mathrm{r}$ jantan 0,977) dan ternak betina $(\mathrm{r}$ betina $=0,971)$. Menurut Ramusia (2011), hubungan antara ukuran dimensi tubuh dan bobot badan kambing kacang jantan dan betina di Kabupaten Konawe Utara umur 6 bulan sampai 48 bulan bersifat positif dan berpengaruh sangat nyata $(\mathrm{P}<0,01)$, yang berarti bahwa apabila ukuran dimensi tubuh meningkat maka bobot badan akan meningkat $\left(r^{2}=0,573\right)$. Sedangkan Soares (2012) menyatakan selain terdapat hubungan yang positif, juga terdapat hubungan negatif kuat antara pertambahan panjang badan dengan pertambahan bobot badan ternak kambing jantan kacang $\quad(\mathrm{r}=-0,84)$. Untuk memperoleh persamaan pendugaan yang lebih teliti maka ukuran dimensi tubuh kambing kacang jantan maupun betina dipelajari hubungannya dengan bobot badan berdasarkan sebaran grafik yang disajikan pada Gambar 1, Gambar 2, dan Gambar 3. 


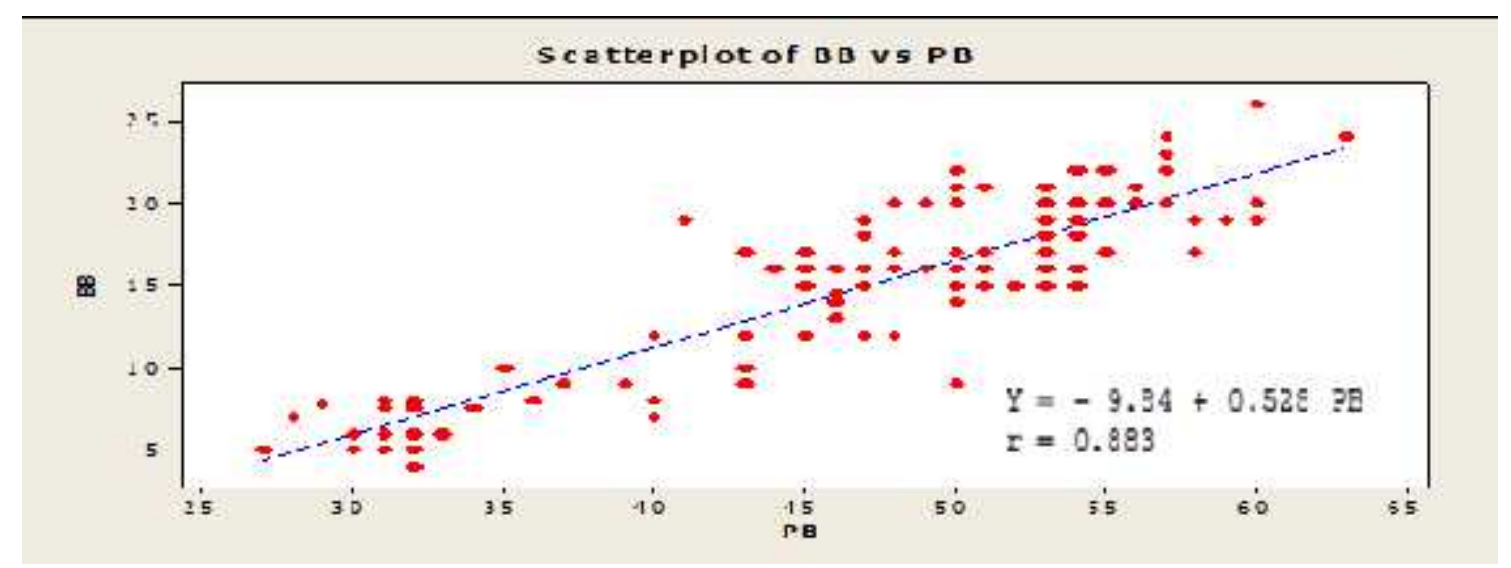

Gambar 1. Hubungan antara bobot badan dengan panjang badan kambing kacang di daerah transmigrasi

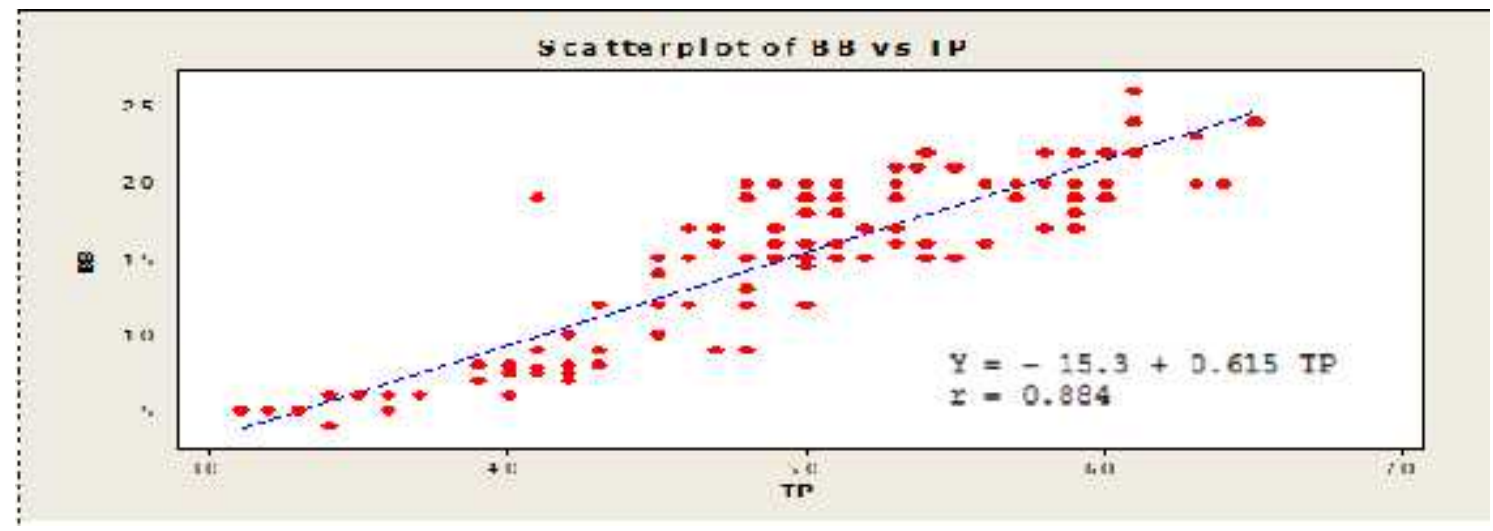

Gambar 2. Hubungan antara bobot badan dengan tinggi pundak kambing kacang di daerah transmigrasi

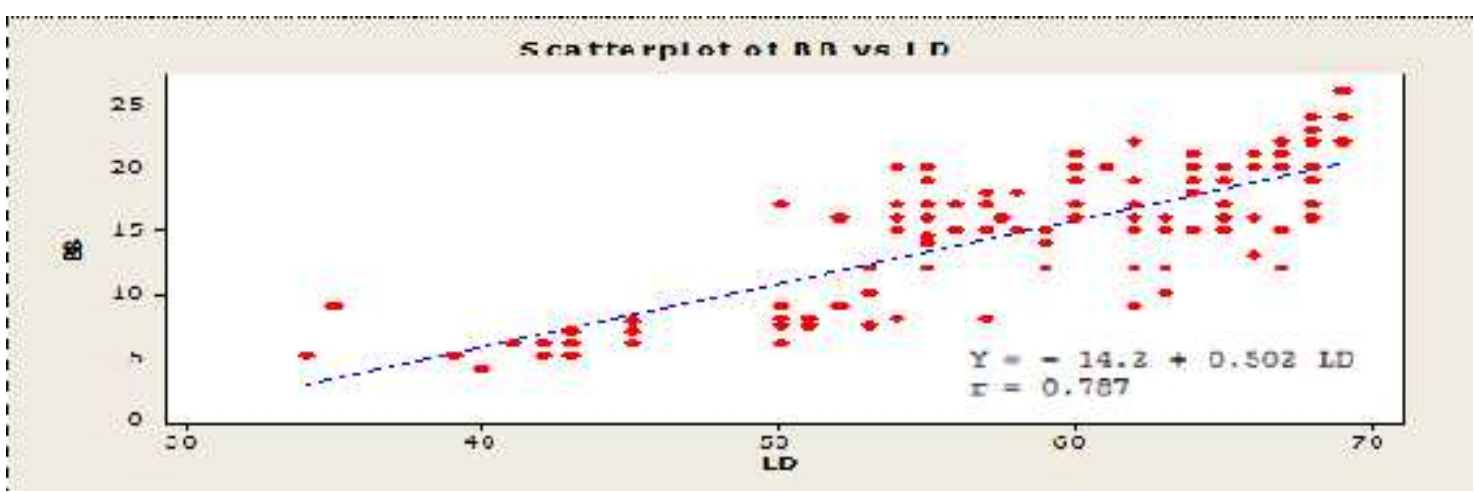

Gambar 3. Hubungan antara bobot badan dengan lingkar dada kambing kacang di daerah transmigrasi

Gambar 1, Gambar 2, hubungan ukuran dimensi tubuh yaitu panjang badan, tinggi pundak dan lingkar dada memperlihatkan penyebaran titik-titik yang berbeda tetapi cenderung membentuk garis linear artinya ada hubungan yang erat antara bobot badan dengan ukuran dimensi tubuh dengan nilai korelasi secara berturut-turut $\mathrm{r}=$ $0,883, r=0.884, r=0,787$. Pendugaan bobot badan kambing kacang di daerah transmigrasi dengan persamaan $\mathrm{Y}=-9,84+0,528 \mathrm{~PB}$ mengandung arti bahwa setiap penambahan 1 $\mathrm{cm}$ panjang badan, akan meningkatkan penambahan bobot badan sebesar $0,528 \mathrm{~kg}$. Pendugaan bobot badan dengan persamaan Y $=-15,3+0,615 \mathrm{TP}$ mengandung arti bahwa setiap penambahan $1 \mathrm{~cm}$ tinggi pundak akan meningkatkan penambahan bobot badan sebesar $0,615 \mathrm{~kg}$. Selanjutnya pendugaan bobot badan dengan persamaan $\mathrm{Y}=-14,2+$ 
0,502 LD mengandung arti bahwa setiap penambahan $1 \mathrm{~cm}$ lingkar dada akan meningkatkan penambahan bobot badan sebesar $0,502 \mathrm{~kg}$.

Data pada Tabel 2 menunjukan bahwa untuk menentukan bobot badan kambing kacang jantan di daerah non transmigrasi pada umur $\leq 12$ bulan adalah tinggi pundak dengan nilai korelasi 0,876 , sementara kambing betina adalah panjang badan dengan nilai korelasi 0,836. Pada umur $13-24$ bulan untuk menentukan bobot badan kambing kacang jantan dan betina adalah tinggi pundak dengan nilai korelasi 0,604 dan 0,424. Untuk menentukan bobot badan kambing kacang jantan umur $>24$ bulan adalah tinggi pundak dengan nilai korelasi 0,284, Untuk menentukan bobot badan kambing kacang betina adalah lingkar dada dengan nilai korelasi 0,253.

Garnis (2013) menyatakan bahwa lingkar dada merupakan parameter penduga bobot badan terbaik pada semua tingkatan umur. Pertambahan bobot badan akan diikuti dengan pertambahan lingkar dada. Lingkar dada berkorelasi sangat nyata $(\mathrm{P}<0,01)$ terhadap bobot badan. Ilham (2012) menambahkan bahwa lingkar dada, tinggi kepala, dan lebar dada memiliki korelasi tertinggi terhadap bobot badan sehingga dapat dijadikan penduga bobot badan kambing.

Yusnadirawan (2005) menambahkan hubungan antara bobot badan dengan ukuranukuran tubuh kambing kacang di Kecamatan Moramo Kabupaten Konawe Selatan umur 1324 bulan atau umur sebelum disapih sampai dewasa adalah positif dan sangat nyata $(\mathrm{P}<0,01)$, yang berarti bahwa apabila bobot badan meningkat maka ukuran tubuh meningkat $\left(\mathrm{r}^{2}=0,924\right)$, dan hasil penelitian Adsmi (2005) di Kecamatan Soropia menunjukan $\left(\mathrm{r}^{2}=0,863\right)$. Untuk memperoleh persamaan pendugaan yang lebih teliti maka ukuran dimensi tubuh kambing kacang jantan maupun betina dipelajari hubungannya dengan bobot badan berdasarkan sebaran grafik yang disajikan pada Gambar 4, Gambar 5, dan Gambar 6.

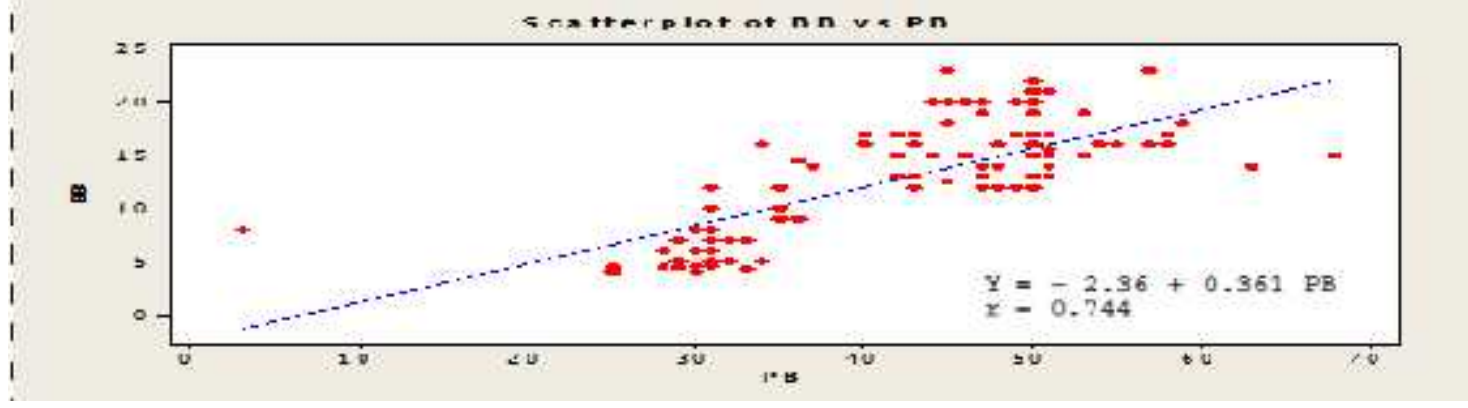

Gambar 4. Hubungan antara bobot badan dengan panjang badan kambing kacang di daerah non transmigrasi

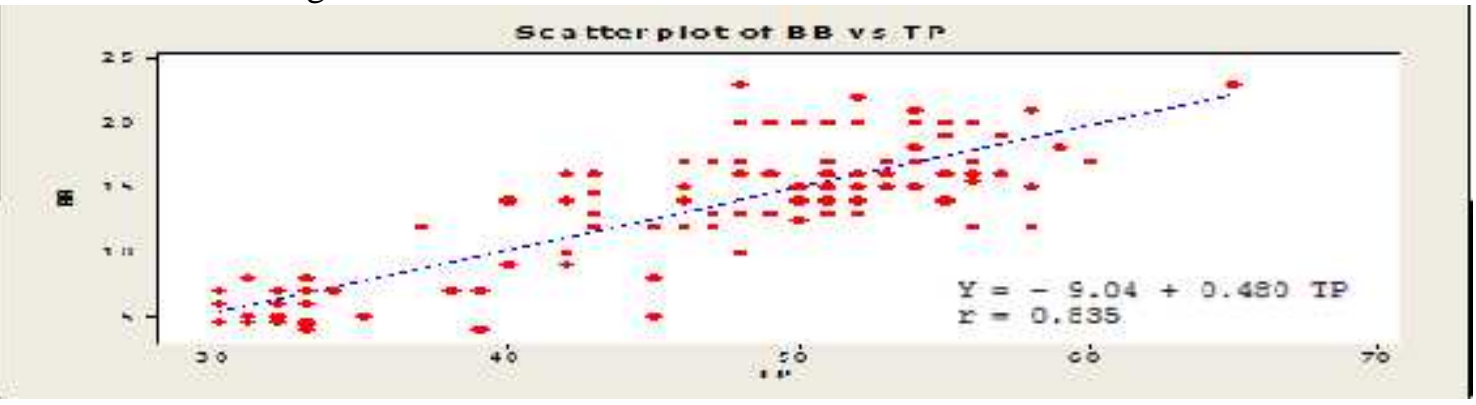

Gambar 5. Hubungan antara bobot badan dengan tinggi pundak kambing kacang di daerah non transmigrasi

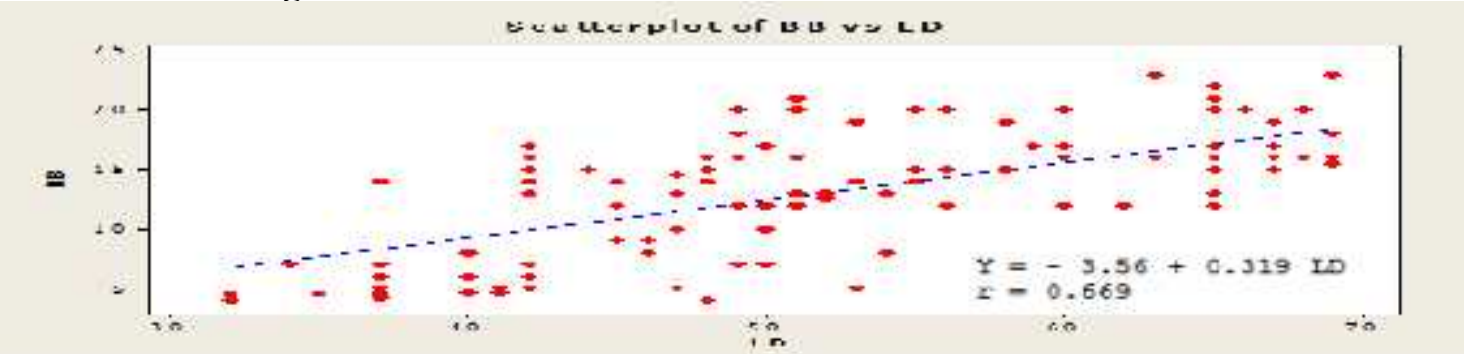


Gambar 6. Hubungan antara bobot badan dengan lingkar dada kambing kacang di daerah non transmigrasi

Gambar 6, Gambar 7, dan Gambar 8, hubungan ukuran dimensi tubuh yaitu panjang badan, tinggi pundak dan lingkar dada memperlihatkan penyebaran titik-titik yang berbeda tetapi cenderung membentuk garis linear, artinya ada hubungan yang erat antara bobot badan dengan ukuran dimensi tubuh dengan nilai korelasi secara berturut-turut $\mathrm{r}=$ $0,744, r=0,835, \quad r=0,669$. Pendugaan bobot badan kambing kacang di daerah non transmigrasi dengan persamaan $\mathrm{Y}=-2,36+$ 0,361 PB mengandung arti bahwa setiap penambahan $1 \mathrm{~cm}$ panjang badan, akan meningkatkan penambahan bobot badan sebesar 0,361 kg. Pendugaan bobot badan dengan persamaan $\mathrm{Y}=-9,04+0,480 \mathrm{TP}$ mengandung arti bahwa setiap penambahan 1 $\mathrm{cm}$ tinggi pundak akan meningkatkan penambahan bobot badan sebesar $0,480 \mathrm{~kg}$. Selanjutnya pendugaan bobot badan dengan persamaan $\mathrm{Y}=-3,56+0,319 \mathrm{LD}$ mengandung arti bahwa setiap penambahan 1 $\mathrm{cm}$ lingkar dada akan meningkatkan penambahan bobot badan sebesar 0,319 kg.

Berdasarkan data tersebut diperoleh nilai korelasi yang sangat kuat antara tinggi pundak dengan bobot badan yaitu $r=0,835$. Tingginya nilai koefisien korelasi yang diperoleh antara bobot badan dan tinggi pundak menunjukan bahwa tinggi pundak mempunyai pertumbuhan yang baik mengikuti pertambahan bobot badan dibandingkan dengan panjang badan, dan lingkar dada.

\section{KESIMPULAN}

1. Rata-rata bobot badan kambing kacang jantan dan betina di daerah transmigrasi tertinggi terdapat pada umur $\geq 24$ bulan, masing-masing $19.3 \pm 3.5$ dan $18.2 \pm 2.8 \mathrm{~kg}$. Sedangkan rataan bobot badan kambing kacang jantan dan betina di daerah non transmigrasi tertinggi terdapat pada umur $\geq 24$ bulan, masing-masing $17.6 \pm 4.7$ dan $17.1 \pm 2.8 \mathrm{~kg}$.

2. Bobot badan kambing kacang jantan di daerah transmigrasi pada umur $\leq 12$ bulan dan umur 13-24 bulan berkorelasi sangat kuat dengan tinggi pundak, dan umur $\geq 24$ bulan berkorelasi dengan lingkar dada. Sedangkan bobot badan kambing kacang jantan umur $\leq 12$ bulan, 13-24 bulan dan $\geq 24$ bulan di daerah non transmigrasi berkorelasi sangat kuat dengan tinggi pundak.

3. Bobot badan kambing kacang betina di daerah transmigrasi pada umur $\leq 12$ bulan dan umur 13-24 bulan berkorelasi sangat kuat dengan tinggi pundak, dan umur $\geq 24$ bulan berkorelasi dengan panjang badan. Sedangkan bobot badan kambing kacang betina di daerah non transmigrasi umur $\leq$ 12 bulan berkorelasi dengan panjang badan, 13-24 bulan berkorelasi dengan tinggi pundak dan umur $\geq 24$ bulan berkorelasi dengan lingkar dada.

\section{DAFTAR PUSTAKA}

Adsmi, Y. 2005. Hubungan Antara Bobot Badan Dengan Ukuran-Ukuran Tubuh Kambing Kacang di Kecamatan Moramo Kabupaten Konawe Selatan. Skripsi. Fakultas Pertanian Universitas Halu Oleo. Kendari.

Agung, P. 2010. Petunjuk Teknis Budidaya Ternak Kambing (Materi Pelatihan Agribisnis bagi KMPH). BPTP Sumatera Selatan, Report No. 51. STE. Final. Palembang.

Garnis T. 2013. Hubungan Ukuran-ukuran Tubuh Dengan Bobot Badan Kambing Jawarandu Jantan di Kabupaten Brebes. Skripsi. Fakultas Peternakan dan Pertanian Universitas Diponegoro.

Ilham, F. 2012. Karakteristik fenotip sifat kualitatif dan kuantitatif kambing Kacang di kabupaten bone bolango. Program Studi Peternakan. Fakultas Pertanian. Universitas Negeri Gorontalo.

Mersi. 2014. Hubungan Antara Ukuran-ukuran Tubuh Dengan Bobot Badan Kambing Kacang di Kecamatan Binongko Kabupaten Wakatobi. Skripsi. Fakultas Peternakan Universitas Halu Oleo. Kendari. 
Ramusia. 2011. Hubungan Antara Ukuran Dimensi Tubuh dan Bobot Badan Ternak Kambing Kacang (Capra Hircus) di Kabupaten Konawe Utara. Skripsi. Fakultas Pertanian Universitas Halu Oleo. Kendari.

Rosmin. 2002. Hubungan Antara Bobot Badan Dengan Ukuran-Ukuran Tubuh Kambing Kacang di Kecamatan Siompu Kabupaten Buton. Skripsi. Fakultas Pertanian Universitas Haluoleo. Kendari.

Soares, S.P. 2012. Korelasi Antara Pertambahan Bobot Badan dan Ukuran Linier Tubuh Ternak Kambing Jantan Kacang pada Pemberian Kombinasi Daun Lamtoro (Leucaena leucocephala), Daun Turi (Sesbania grandiflora), Daun Waru (Hibiscus sepium), Daun Gamal (Gliricidia sepium) dan Daun Pisang (Musa paradisiaca). Skripsi. Fakultas Pertanian Universidade Nacional Timor Lorosa'e. Dili.

Yusnadirawan. 2005. Hubungan Antara Ukuran Dimensi Tubuh Dengan Bobot Badan pada Kambing Kacang di Kecamatan Soropia. Skripsi. Fakultas Pertanian Universitas Haluoleo. Kendari. 